\title{
Accumulation of cadmium, copper and zinc in selected natural Viola taxa in Turkish Mediterranean serpentine soils
}

Ahmet AKSOY $\odot$

Akdeniz University, Science Faculty, Department of Biology, Antalya, Turkey

aksoy@akdeniz.edu.tr

Received : 22.09.2021

Accepted : 13.10 .2021

Online : $: 21.10 .2021$

\section{Türkiye Akdeniz serpantin topraklarında seçilmiş doğal Viola taksonlarının kadmiyum, bakır ve çinko akümülasyonu}

\begin{abstract}
Currently, 55 serpentine areas have been determined in Turkey. More than $60 \mathrm{Ni}$-accumulators and more than 43 serpentine-endemics are known from these areas. Within our field studies in the Mediterranean phytogeographic region, 8 Viola taxa distributed in serpentine areas and their respective soil samples were collected. $\mathrm{Cd}, \mathrm{Cu}$, and $\mathrm{Zn}$ concentrations of the soil and plant samples were investigated. After the plant and soil samples were digested in the microwave, metal measurements were made using a ICP-OES device. As a result of the $\mathrm{Cd}, \mathrm{Cu}$, and $\mathrm{Zn}$ measurements, none of the 8 Viola taxa collected from different localities were found to be hyperaccumulators. However, it was determined that Viola kizildaghensis has an accumulator feature in terms of $\mathrm{Zn}$.
\end{abstract}

Key words: accumulator, serpentine soil, Viola taxa, Zinc

Özet: Ülkemizde 55 serpantin alan belirlenmiş ve bu alanlarda 60'dan fazla Ni akümülatörü ve 43'den fazla sayıda serpantin endemiği olduğu tespit edilmiştir. Akdeniz fitocoğrafik bölgesinde yapmış olduğumuz arazi çalışmalarında serpantin alanlarda yayılış gösteren 8 Viola taksonu ve bunların yetiştiği toprak örnekleri toplandı. Toplanan 8 Viola taksonunun yetiştiği topraklar ve bitkilerdeki $\mathrm{Cd}, \mathrm{Cu}$, ve $\mathrm{Zn}$ konsantrasyonları araştırılmıştır. Bitki ve toprak örnekleri mikrodalgada çözüldükten sonra metal ölçümleri ICP-OES cihazında yapılmıştır. Farklı lokalitelerden toplanan 8 Viola taksonunda yapılan $\mathrm{Cd}, \mathrm{Cu}$, ve $\mathrm{Zn}$ ölçümleri sonucunda hiçbir bitkide hiperakümülatör özelliği tespit edilememiştir. Ancak, Viola kizildaghensis bitkisinin Zn yönünden akümülator özelliğinin olduğu belirlenmiştir.

Anahtar Kelimeler: akümülatör, serpantin topraklar, Viola taksonları, çinko

Citation: Aksoy A (2021). Accumulation of cadmium, copper and zinc in selected natural Viola taxa in Turkish Mediterranean serpentine soils. Anatolian Journal of Botany 5(2): 138-143.

\section{Introduction}

It is becoming increasingly important to use hyperaccumulator or accumulator plants in stabilizing environments contaminated with heavy metals. Among heavy metals, $\mathrm{Cd}, \mathrm{Cu}$, and $\mathrm{Zn}$ are toxic elements that are easily taken up by plants and translocated to different parts of the plant.

Some of the earlier dry matter concentration thresholds for hyperaccumulation of trace elements in terrestrial plants have been revised recently. Recommendations by Krämer (2010), van der Ent et al. (2013), Remigio et al. (2020) and Peng et al. (2020), for plants that are growing in their natural habitat, are as follows: $\mathrm{Cd}>100 \mathrm{mg} \mathrm{kg}^{-1}$; $\mathrm{Cu} 300$ $\mathrm{mg} \mathrm{kg}{ }^{-1} ; \mathrm{Zn} \mathrm{3,000} \mathrm{mg} \mathrm{kg}^{-1}$. The global hyperaccumulator database (www.hyperaccumulators.org) includes 721 hyperaccumulators, and their number is growing. Most hyperaccumulators species (532 species) are identified as $\mathrm{Ni}$ hyperaccumulators, while hyperaccumulators of $\mathrm{Cd}$ (7 species) and As (5 species), which currently pose the greatest threat to human health, are notably scarce (Reeves et al., 2018). At the same time, hyperaccumulator plants must manage to grow and to survive in an environment rich in metals.

Many studies have been carried out about serpentine areas in Turkey. Until now, 55 serpentine areas have been examined in Turkey and $62 \mathrm{Ni}$-accumulators and more than 43 serpentine-endemics have been reported from these areas (Reeves, 1998; Reeves et al., 1983, 2001, 2009; Reeves and Adıgüzel, 2004, 2008; Adıgüzel and Reeves,
2012; Altınözlü et al., 2012; Aksoy et al., 2015; Çelik et al., 2018). According to the Flora of Turkey, it is reported that there are 248 plants specific to serpentine areas, of which 119 are serpentinophytes and 129 are serpentinophages (Kurt et al., 2013; Özdeniz et al. 2017). According to Kurt et al. 2013 and Özdeniz et al., 2017, Viola species were not recorded in the serpentine flora of Turkey.

The hyperaccumulator/accumulator properties of some Viola species have been investigated by various researchers. Hyperaccumulator/accumulator properties have been determined for Viola calaminaria (Ging.) Nauenb., $V$. guestphalica Nauenb. ( $\mathrm{Zn}$ and $\mathrm{Pb}$ ), $V$. baoshanensis W.S.Shu, WLiu \& CY.Lan (Cd), V. principis H.Boissieu (As, $\mathrm{Cd}$ and $\mathrm{Pb}$ ), V. kopaonikensis, Pančić ex Tomović \& Niketić, V. elegantula Schott and V. beckiana F.Fiala ex Beck ( $\mathrm{Ni}, \mathrm{Cd}$, and $\mathrm{Pb})$, as well as $V$. arsenica Beck, V. allcharensis G.Beck and V. macedonica Boiss. \& Heldr. (As, Sb and Tl) (Brooks, 1998; Jedrzejczyk et al., 2002; Liu et al., 2004; Lei et al., 2008; Stevanović et al., 2010; Bačeva et al., 2014: Tomović et al., 2021).

The genus Viola L. is a member of the family Violaceae and is represented by approximately 600 taxa in the World (Marcussen et al., 2015; Düşen et al., 2018). In Turkey the genus Viola is represented by 36 taxa, of which 14 are endemic (Coode and Cullen, 1965; Davis et al., 1988; Yıldırımlı, 2000; Dinç, 2012; Adıgüzel and Reeves, 2012; Knoche and Marcussen, 2016; Düşen et al., 2018).

According to the current literature, there is no study that investigated the hyperaccumulator/accumulator properties 
of Viola taxa from Turkey. In this study, 8 Viola taxa were collected from serpentine areas of the Mediterranean Region and $\mathrm{Cd}, \mathrm{Cu}$ and $\mathrm{Zn}$ concentrations of the soils in which these plants grow were determined. The aim of this study was to investigate whether some of the Viola taxa studied have hyperaccumulator/accumulator properties for $\mathrm{Cd}, \mathrm{Cu}$ and $\mathrm{Zn}$.

\section{Materials and Methods}

\subsection{Materials}

Soil samples and specimens of the investigated 8 Viola taxa were collected from serpentine areas in the Mediterranean phytogeographical region in 2016 (Table 1). For each taxon, three soil samples (24 in total) were collected from the areas where the Viola taxa (Table 1) were growing. Plant and soil samples were collected in 3 replicates for heavy metal analysis. Further, the collected specimens were stored in the Herbarium of Akdeniz University.

\subsection{Sampling}

Soils were taken from the $0-5 \mathrm{~cm}$ zone, brought to the laboratory, sieved with a standard $4 \mathrm{~mm}$ sieve and were than air-dried. At least 15-50 adult plants were randomly selected and collected from each site. Two to ten plants were retained as herbarium specimens. The remaining other plants from each site were divided into above- and belowground parts. These were transferred to the laboratory in plastic bags. Plant samples were washed with tap water, followed by deionized water. They were dried in an oven $\left(80{ }^{\circ} \mathrm{C}\right)$ until they reached constant weight and brittleness. The samples were subsequently ground with a pestle and mortar. Homogenized plant materials and soil samples were then stored in clean paper bags before heavy-metal analysis.

\subsection{Chemical and statistical analyses}

Soil samples $(0.5 \mathrm{~g}$ dry weight $)$ were digested with $10 \mathrm{ml}$ of pure $\mathrm{HNO}_{3}(65 \%)$, using a CEM-MARS 5 microwave digestion system (digestion conditions were the following: maximum power $1200 \mathrm{~W}$; power $100 \%$; ramp time $20 \mathrm{~min}$, pressure $180 \mathrm{psi}$; temperature $180{ }^{\circ} \mathrm{C}$; and hold time 10 min). After digestion, the volume of each sample was adjusted to $25 \mathrm{~mL}$ by using double-deionized water. Homogenized plant samples ( $0.5 \mathrm{~g}$ dry weight) were also prepared using the same procedure as for heavy-metal analysis. The soil and plant samples were analyzed for $\mathrm{Cd}$, $\mathrm{Cu}$, and $\mathrm{Zn}$ by ICP-OES; Varian-Liberty II. All chemicals were of analytical reagent grade. Standard peach leaves (NIST, SRM-1547) were used as a reference material. All analytical procedures were performed using this reference material. Soil and plant samples were digested in triplicate and analyzed. The means and standard deviation (SD) of the data were calculated using SPSS v15.0 (SPSS Inc., Chicago, IL, USA).

Table 1. Collecting sites and protection categories of Viola taxa.

\begin{tabular}{|c|c|c|c|c|}
\hline No & Collected species & Turkish name & Collecting places & IUCN \\
\hline 1 & $\begin{array}{l}\text { Viola alba Besser subsp. } \\
\text { dehnhardtii (Ten.) W. Becker }\end{array}$ & $\begin{array}{l}\text { Meşe } \\
\text { menekşesi }\end{array}$ & $\begin{array}{l}\text { B5: Kayseri, Yahyalı Çamlica village, Kayapınar location, } \\
\text { 1410m, 11.08.2016, Aksoy2645 }\end{array}$ & - \\
\hline 2 & V. dirimliensis Blaxland & $\begin{array}{l}\text { Dirmil } \\
\text { menekşesi }\end{array}$ & $\begin{array}{l}\text { C2: Burdur-Altınyayla, Dirmil Pass, } 1630 \mathrm{~m}, 21.04 .2016 . \\
\text { Aksoy } 2569\end{array}$ & CR \\
\hline 3 & V. heldreichiana Boiss. & $\begin{array}{l}\text { Gök } \\
\text { menekșe }\end{array}$ & $\begin{array}{l}\text { B5: Kayseri, Yahyalı Çamlica village, Kayapınar location, } \\
\text { 1410m, 04.04.2016, Aksoy } 2605\end{array}$ & \\
\hline 4 & V. kitaibeliana Roem. \& Schult. & $\begin{array}{l}\text { Yabani } \\
\text { menekşe }\end{array}$ & $\begin{array}{l}\text { B5: Kayseri, Yahyalı Çamlıca to Ulupınar village, } 2 \mathrm{~km} \\
\text { from Ulupınar village } 1370 \mathrm{~m}, 04.04 .2016, \text { Aksoy } 2608\end{array}$ & - \\
\hline 5 & V. kizildaghensis Dinç \& Y1ld. & $\begin{array}{l}\text { Pembe } \\
\text { menekșe }\end{array}$ & $\begin{array}{l}\text { C3: Konya-Derebucak, Çamlık village, Kızıldağ1, Akçeşme } \\
\text { location } 1450 \mathrm{n}, 26.00 .2016 . \text { Aksoy } 2642\end{array}$ & $\mathrm{CR}$ \\
\hline 6 & $V$. modesta Fenzl & $\begin{array}{l}\text { Sahra } \\
\text { menekșesi }\end{array}$ & $\begin{array}{l}\text { C4: Konya-Bozkır, Üçpınar village, Tufan Deresi,1990, } \\
\text { 28.04.2016. Aksoy 2581 }\end{array}$ & - \\
\hline 7 & $\begin{array}{l}\text { V. sandrasea Melch. subsp. } \\
\text { sandrasea }\end{array}$ & $\begin{array}{l}\text { Sandras } \\
\text { menekşesi }\end{array}$ & $\begin{array}{l}\text { C2: Muğla-Köyceğiz, Sandras Dağ1 } 1830 \text { m, 21.04.2016. } \\
\text { Aksoy } 2563\end{array}$ & EN \\
\hline 8 & V. suavis M. Bieb. & $\begin{array}{l}\text { Akgöz } \\
\text { menekşe }\end{array}$ & $\begin{array}{l}\text { C5: Hatay- Arsuz, above the village of Kale, Kizıldağ, } \\
\text { 17.04.2016 Aksoy } 2586\end{array}$ & - \\
\hline
\end{tabular}

\section{Results and Discussion}

The minimum, maximum and mean concentrations of $\mathrm{Cd}$, $\mathrm{Cu}$, and $\mathrm{Zn}$ in the investigated soils and aboveground and underground parts of the Viola taxa are given in Table 2 and the mean concentrations of $\mathrm{Cd}, \mathrm{Cu}$, and $\mathrm{Zn}$ are further shown in Figure 1.

While the Cd concentrations ranged between 3.40-33.75 $\mathrm{mg} \mathrm{kg}^{-1}$ in the studied soils, it was found that the values varied between $0.15-1.86 \mathrm{mg} \mathrm{kg}^{-1}$ in the underground parts and between $0.68-1.71 \mathrm{mg} \mathrm{kg}^{-1}$ in the aboveground parts of the Viola taxa. The highest Cd concentration $\left(33.75 \mathrm{mg} \mathrm{kg}^{-}\right.$ ${ }^{1}$ ) was detected in the soils where $V$. heldreichiana grew and the lowest $\mathrm{Cd}$ concentration $\left(3.40 \mathrm{mg} \mathrm{kg}^{-1}\right)$ was found in the soils where $V$. modesta samples grew (Table 2). It has been reported that the $\mathrm{Cd}$ concentration of $V$. baoshanensis, which grows in the Baoshan lead / zinc mine field in Hunan, China, varies between $456-2310 \mathrm{mg} \mathrm{kg}^{-1}$ in the aboveground parts and between $233-1846 \mathrm{mg} \mathrm{kg}^{-1}$ in the underground parts (Wei et al., 2004).

$\mathrm{Cu}$ concentrations ranged between $7.51-33.30 \mathrm{mg} \mathrm{kg}^{-1}$ in the studied soils, between $1.21-6.31 \mathrm{mg} \mathrm{kg}^{-1}$ in the underground parts and between $2.57-4.69 \mathrm{mg} \mathrm{kg}^{-1}$ in the aboveground parts of the investigated Viola taxa. The highest $\mathrm{Cu}$ concentration $\left(30.85 \mathrm{mg} \mathrm{kg}^{-1}\right)$ was detected in the soils where the sampled $V$. heldreichiana grew while the lowest $\mathrm{Cu}$ concentration $\left(7.51 \mathrm{mg} \mathrm{kg}^{-1}\right)$ was found in the soils where $V$. kizildaghensis grew (Table 2).

While the $\mathrm{Zn}$ concentrations ranged between 5.65-95.25 $\mathrm{mg} \mathrm{kg}{ }^{-1}$ in the studied soils, $\mathrm{Zn}$ concentrations for the investigated Viola taxa varied between $4.65-69.25 \mathrm{mg} \mathrm{kg}^{-1}$ in the underground parts and between $12.15-64.65 \mathrm{mg} \mathrm{kg}^{-1}$ in the aboveground parts. The highest $\mathrm{Zn}$ concentration (33.30 mg kg-1) was detected in the soils where the investigated $V$. heldreichiana samples grew and the lowest 
$\mathrm{Zn}$ concentration $\left(9.68 \mathrm{mg} \mathrm{kg} \mathrm{kg}^{-1}\right)$ was found in the soils where $V$. sandrasea subsp. sandrasea samples grew (Table 2).

The investigated $\mathrm{Cd}$ and $\mathrm{Cu}$ concentrations were found to be higher in the soil compared to the underground and aboveground parts of the plants. However, $\mathrm{Zn}$ concentrations in $V$. dirimliensis, $V$. kizildaghensis, $V$. suavis and $V$. sandrasea subsp. sandrasea were found to be higher, both in the underground and aboveground parts of the plant, than the concentrations of the soil samples (Fig. $1)$.

Table 2. Minimum, maximum and mean concentration of $\mathrm{Cd}, \mathrm{Cu}$, and $\mathrm{Zn}$ in underground and aboveground parts of the investigated Viola species and soils collected from serpentine areas in the Mediterranean region of Turkey $\left(\mathrm{mg} \mathrm{kg}^{-1}\right.$ dry weight $\left.\pm \mathrm{SD}\right)$.

\begin{tabular}{|c|c|c|c|c|c|c|c|c|c|c|}
\hline \multirow[b]{2}{*}{ Plant species } & \multirow[b]{2}{*}{ Elements } & \multicolumn{3}{|c|}{ Soil } & \multicolumn{3}{|c|}{ Underground } & \multicolumn{3}{|c|}{ Aboveground } \\
\hline & & Cd & $\mathrm{Cu}$ & $\mathbf{Z n}$ & Cd & $\mathbf{C u}$ & $\mathbf{Z n}$ & Cd & $\mathrm{Cu}$ & $\mathbf{Z n}$ \\
\hline \multirow{4}{*}{$\begin{array}{l}\text { V. alba subsp. } \\
\text { dehnhardtii }\end{array}$} & $\min$ & 10,68 & 16,82 & 30,94 & 1,44 & 5,74 & 42,99 & 1,00 & 2,95 & 23,72 \\
\hline & $\max$ & 10,83 & 16,84 & 31,40 & 1,50 & 5,76 & 43,35 & 1,03 & 2,98 & 23,80 \\
\hline & mean & 10,75 & 16,83 & 31,17 & 1,47 & 5,75 & 43,17 & 1,02 & 2,96 & 23,76 \\
\hline & $\mathrm{SD}$ & $\pm 0,11$ & $\pm 0,01$ & $\pm 0,32$ & $\pm 0,04$ & $\pm 0,01$ & $\pm 0,25$ & $\pm 0,02$ & $\pm 0,02$ & $\pm 0,06$ \\
\hline \multirow{4}{*}{ V. dirimliensis } & $\min$ & 7,77 & 10,24 & 13,31 & 0,97 & 2,12 & 15,78 & 0,93 & 2,57 & 19,13 \\
\hline & $\max$ & 7,80 & 10,35 & 13,49 & 1,06 & 2,16 & 15,80 & 0,96 & 2,60 & 19,49 \\
\hline & mean & 7,78 & 10,30 & 13,40 & 1,01 & 2,14 & 15,79 & 0,94 & 2,58 & 19,31 \\
\hline & SD & $\pm 0,02$ & $\pm 0,08$ & $\pm 0,13$ & $\pm 0,06$ & $\pm 0,30$ & $\pm 0,01$ & $\pm 0,02$ & $\pm 0,02$ & $\pm 0,26$ \\
\hline \multirow{4}{*}{ V. heldreichiana } & $\min$ & 33,65 & 32,70 & 94,45 & 0,15 & 1,20 & 4,65 & 1,61 & 3,50 & 38,20 \\
\hline & $\max$ & 33,75 & 33,30 & 95,25 & 0,17 & 1,30 & 4,75 & 1,71 & 3,55 & 40,15 \\
\hline & mean & 33,70 & 32,91 & 94,88 & 0,16 & 1,25 & 4,71 & 1,66 & 3,51 & 38,90 \\
\hline & $\mathrm{SD}$ & $\pm 0,13$ & $\pm 0,30$ & $\pm 0,40$ & $\pm 0,02$ & $\pm 0,05$ & $\pm 0,05$ & $\pm 0,32$ & $\pm 0,02$ & $\pm 0,98$ \\
\hline \multirow{4}{*}{ V. kitaibeliana } & $\min$ & 30,51 & 23,70 & 86,05 & 0,57 & 2,30 & 17,15 & 1,44 & 3,05 & 34,10 \\
\hline & $\max$ & 30,85 & 24,35 & 88,25 & 0,59 & 2,35 & 17,40 & 1,50 & 3,15 & 34,85 \\
\hline & mean & 30,68 & 24,00 & 86,96 & 0,58 & 2,31 & 17,25 & 1,47 & 3,10 & 34,56 \\
\hline & SD & $\pm 0,36$ & $\pm 0,32$ & $\pm 1,10$ & $\pm 0,02$ & $\pm 0,26$ & $\pm 0,12$ & $\pm 0,12$ & $\pm 0,05$ & $\pm 0,37$ \\
\hline \multirow{4}{*}{ V. kizildaghensis } & $\min$ & 11,46 & 7,51 & 29,67 & 1,84 & 5,05 & 68,25 & 1,08 & 2,77 & 64,36 \\
\hline & $\max$ & 11,49 & 7,52 & 29,96 & 1,86 & 5,11 & 69,25 & 1,10 & 2,75 & 64,62 \\
\hline & mean & 11,47 & 7,52 & 29,82 & 1,85 & 5,08 & 68,75 & 1,09 & 2,76 & 64,49 \\
\hline & SD & $\pm 0,27$ & $\pm 0,01$ & $\pm 0,21$ & $\pm 0,01$ & $\pm 0,05$ & $\pm 0,70$ & $\pm 0,16$ & $\pm 0,01$ & $\pm 0,18$ \\
\hline \multirow{4}{*}{$V$. modesta } & $\min$ & 3,40 & 10,72 & 35,50 & 1,11 & 5,17 & 17,50 & 1,11 & 4,04 & 21,20 \\
\hline & $\max$ & 3,45 & 10,83 & 35,76 & 1,15 & 5,19 & 17,53 & 1,14 & 4,05 & 21,29 \\
\hline & mean & 3,42 & 10,78 & 35,63 & 1,13 & 5,18 & 17,53 & 1,12 & 4,04 & 21,25 \\
\hline & SD & $\pm 0,04$ & $\pm 0,08$ & $\pm 0,18$ & $\pm 0,03$ & $\pm 0,01$ & $\pm 0,02$ & $\pm 0,02$ & $\pm 0,01$ & $\pm 0,06$ \\
\hline \multirow{4}{*}{$\begin{array}{l}\text { V. sandrasea subsp. } \\
\text { sandrasea }\end{array}$} & $\min$ & 6,89 & 9,68 & 5,65 & 1,31 & 6,27 & 26,47 & 0,68 & 3,92 & 12,15 \\
\hline & $\max$ & 6,93 & 9,76 & 5,87 & 1,33 & 6,31 & 26,91 & 0,70 & 3,96 & 12,48 \\
\hline & mean & 6,91 & 9,72 & 5,76 & 1,32 & 6,29 & 26,69 & 0,69 & 3,94 & 12,32 \\
\hline & $\mathrm{SD}$ & $\pm 0,03$ & $\pm 0,06$ & $\pm 0,16$ & $\pm 0,01$ & $\pm 0,03$ & $\pm 0,32$ & $\pm 0,01$ & $\pm 0,03$ & $\pm 0,23$ \\
\hline \multirow{4}{*}{ V.suavis } & $\min$ & 9,37 & 12,92 & 25,85 & 1,20 & 5,49 & 45,36 & 0,92 & 4,64 & 33,03 \\
\hline & $\max$ & 9,55 & 13,17 & 26,09 & 1,22 & 5,51 & 45,85 & 0,94 & 4,69 & 33,43 \\
\hline & mean & 9,46 & 13,05 & 25,97 & 1,21 & $\mathbf{5 , 5 0}$ & 45,61 & $\mathbf{0 , 9 3}$ & 4,66 & 33,23 \\
\hline & $\mathrm{SD}$ & $\pm 0,13$ & $\pm 0,18$ & $\pm 0,17$ & $\pm 0,01$ & $\pm 0,02$ & $\pm 0,34$ & $\pm 0,012$ & $\pm 0,04$ & $\pm 0,28$ \\
\hline
\end{tabular}

Among the eight Viola taxa studied, $\mathrm{Zn}$ concentrations of $V$. dirimliensis were highest in the aboveground $(19.31 \mathrm{mg}$ $\left.\mathrm{kg}^{-1}\right)$ and slightly lower in the underground parts $(15.79 \mathrm{mg}$ $\left.\mathrm{kg}^{-1}\right)$ and in the soil $\left(13.40 \mathrm{mg} \mathrm{kg}^{-1}\right)$. The $\mathrm{Zn}$ concentrations in the aboveground (64.49 $\mathrm{mg} \mathrm{kg}^{-1}$ ) and underground $\left(68.75 \mathrm{mg} \mathrm{kg}^{-1}\right)$ parts of $V$. kizildaghensis were found to be twice as high as in the soils $\left(29.82 \mathrm{mg} \mathrm{kg}^{-1}\right)$. The fact that the $\mathrm{Zn}$ concentration in the aboveground parts of $V$. kizildaghensis is markedly higher than in the soil where the plants grew indicates that $V$. kizildaghensis has a $\mathrm{Zn}$ accumulator feature. Stevanovic et al. (2010) and Bačeva et al. (2014) examined whether some Viola species in the Alchar region of Macedonia are hyperaccumulators for several heavy metals including $\mathrm{Zn}$. They found that the Viola species studied had an accumulator feature for $\mathrm{Zn}$.

Different ecosystems in many parts of the world have been contaminated by various heavy metals such as $\mathrm{Cd}, \mathrm{Cr}, \mathrm{Cu}$, $\mathrm{Ni}, \mathrm{Pb}, \mathrm{Zn}$. In recent years, hyperaccumulator or accumulator plants have been used as a model in the cleaning of these contaminated environments, and thus to reduce this pollution (Aksoy and Öztürk, 1997; Baker et al., 2000; Prasad, 2005).

Many studies have been carried out about serpentine areas in Turkey with $62 \mathrm{Ni}$-hyperaccumulator plants being recorded in these areas. Most of these plants belong to the Brassicaceae and Asteraceae family. According to these studies, no plant species with $\mathrm{Cd}, \mathrm{Cu}$ and $\mathrm{Zn}$ hyperaccumulator properties were found in Turkey. (Reeves, 1988; Reeves et al., 1983, 2001, 2009; Reeves and Adıgüzel, 2004, 2008; Adigüzel and Reeves, 2012; Altınözlü et al., 2012; Aksoy et al., 2015; Çelik et al., 2018).

A large number of hyperaccumulators in Viola species have been reported in Asian and European countries, for example, $V$. baoshanensis for the hyperaccumulation of cadmium (Liu et al., 2004; Tonin et al., 2001) and V. calaminaria (Tonin et al., 2001) and V. lutea (Sychta et al., 2018) for the hyperaccumulation of zinc. In their study on $V$. boashanensis in China, $\mathrm{Wu}$ et al. (2010) found $\mathrm{Cd}$ concentrations of $1090 \mathrm{mg} \mathrm{kg}^{-1}, \mathrm{~Pb}$ concentrations of 1902 


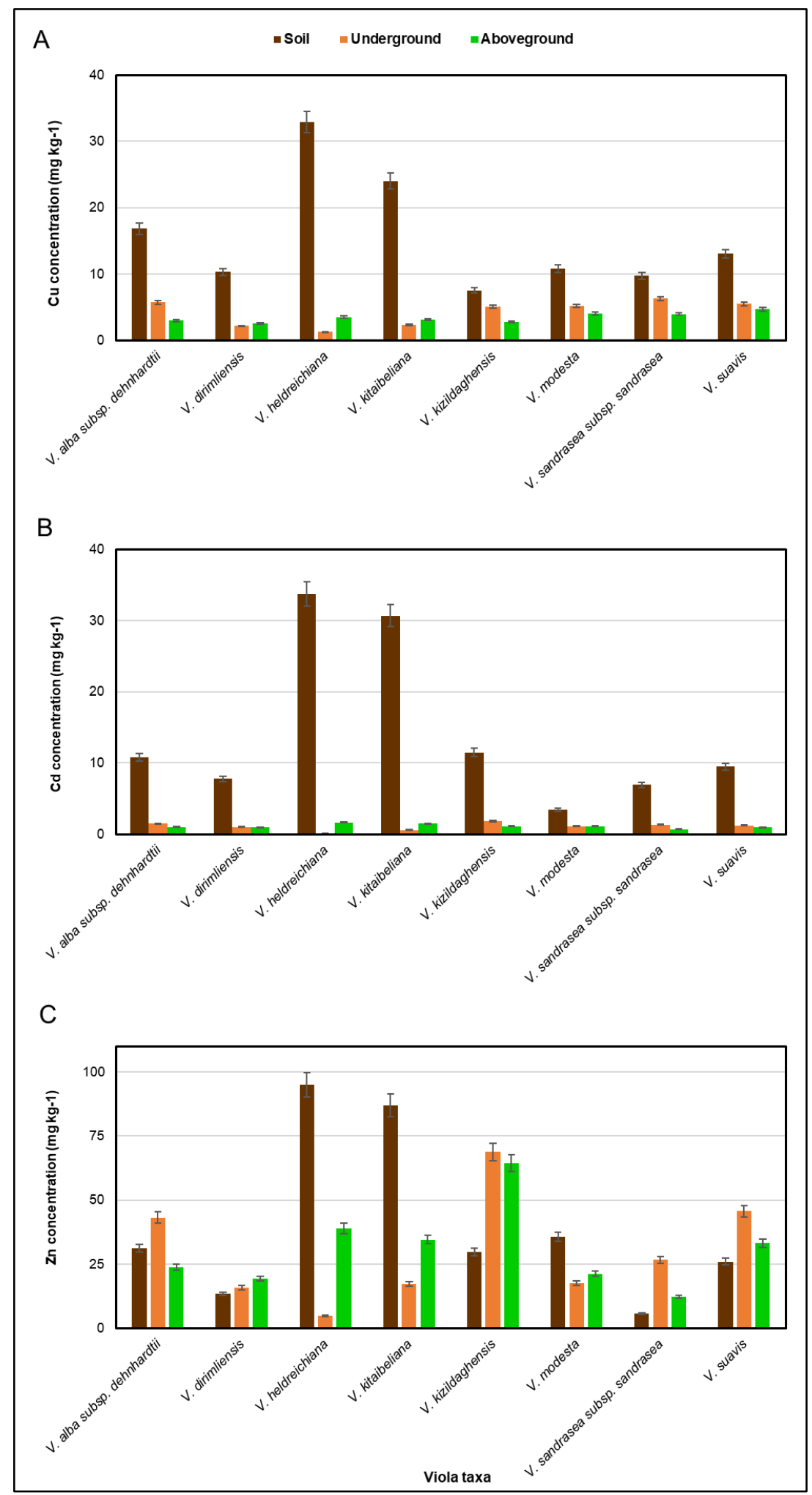

Figure 1. Mean concentrations of $\mathrm{Cd}(\mathbf{A}), \mathrm{Cu}(\mathbf{B})$ and $\mathrm{Zn}(\mathbf{C})$ in the soil and the aboveground and underground parts of the Viola taxa, together with standard errors (S.E.).

$\mathrm{mg} \mathrm{kg}{ }^{-1}$, and $\mathrm{Zn}$ concentration of $3428 \mathrm{mg} \mathrm{kg}^{-1}$. They reported that $V$. boashanensis was a hyperaccumulator plant for $\mathrm{Pb}$ and $\mathrm{Zn}$ as well as for $\mathrm{Cd}$. As a result of this study, no hyperaccumulator properties could be detected for the investigated Viola taxa. However, it has been determined that $V$. dirimliensis, $V$. kizildaghensis, $V$. suavis and $V$. sandrasea subsp. sandrasea accumulate zinc to a certain extent.

\section{Acknowledgments}

This work was part of a project supported by the Scientific Research Projects Coordination Unit of Akdeniz University (Project number: FBA-2016-1982). I would like to thank Jale Çelik and Uğurcan Baran for their help and Aylin Güney for language editing. 


\section{References}

Adıgüzel N, Reeves RD (2012). Important serpentine areas of Turkey and distribution patterns of serpentine endemics and nickel accumulators. Bocconea 24: 7-17.

Aksoy A, Leblebici Z, Prasad MNV (2015). Metal accumulating plants from serpentine habitats of Kızıldağ, Konya Province of Turkey. Australian Journal of Botany 63(3-4): 372-378.

Aksoy A, Öztürk M (1997). Nerium oleander L. as a biomonitor of lead and other heavy metal pollution in Mediterranean environments. The Science of the Total Environment 205: 145-150.

Altı̈özlü H, Karagöz A, Polat T, Ünver İ (2012). Nickel hyperaccumulation by natural plants in Turkish serpentine soils. Turkish Journal of Botany 36: 269-280.

Bačeva K, Stafilov T, Matevski V (2014). Bioaccumulation of heavy metals by endemic Viola species from the soil in the vicinity of the As-Sb-TI mine "Alchar", Republic of Macedonia. International Journal of Phytoremediation 16: 347-365.

Baker AJM, McGrath SP, Reeves RD, Smith JAC (2000). Metal hyperaccumulator plants: A review of the ecology and physiology of a biological resource for phytoremediation of metal-polluted soils. In: Terry N, Banuelos G (eds.). Phytoremediation of contaminated soil and water, Boca Raton: Lewis publishers, pp. 85-107.

Brooks RR (1998). Geobotany and hyperaccumulators. In: Brooks RR (ed). Plants that hyperaccumulate heavy metals. Wallingford: CAB International, pp.55-94.

Coode MJE, Cullen J (1965). Viola L. In: P.H. Davis (ed.). Flora of Turkey and the East Aegean Islands, vol. I, Edinburgh: Edinburgh Univ. Press, pp. 524-533.

Çelik J, Aksoy A, Leblebici Z (2018). Metal hyperaccumulating Brassicaceae from the ultramafic area of Yahyalı in Kayseri province, Turkey. Ecological Research 33: 705-713.

Davis PH, Mill RR, Tan K (1988). Flora of Turkey and the East Aegean Islands. Vol: 10, Edinburgh: Edinburgh University Press.

Dinç M (2012). Viola L. Şu kitapta: Güner A, Aslan S, Ekim T, Vural M, Babaç MT. (eds.) Türkiye Bitkileri Listesi (Damarlı Bitkiler). İstanbul: Nezahat Gökyiğit Botanik Bahçesi ve Flora Araştırmaları Derneği Yayını.

Düşen O, Göktürk RS, Kaya E, Sarpkaya U ve Gürcan B (2018). Morphological and molecular determination of a new Viola species (Violaceae) from Turkey. Phytotaxa 369(1): 37-46.

Hyperaccumulators.org. https://hyperaccumulators.org/ [accessed accessed 08.10. 2021].

Jedrzejczyk M, Rostański A, Malkowski A (2002). Accumulation of zinc and lead in selected taxa of the genus Viola 1 . Acta Biologica Cracoviensia Series Botanica 44: 49-55.

Knoche G, Marcussen T (2016). Viola barhalensis (Violaceae), a new species from northeastern Turkey. Phytotaxa 275(1): 14-22.

Kramer Ü (2010). Metal hyperaccumulation in plants. Annual Review of Plant Biology 61: 517-534.

Kurt L, Ozbey BG, Kurt F, Ozdeniz E. Bolukbaş1 A (2013). Serpentine Flora of Turkey. Biological Diversity and Conservation 6(1): 134-152.

Lei M, Chen TB, Huang ZC, Wang YD, Huang YY (2008). Simultaneous compartmentalization of lead and arsenic in cohyperaccumulator Viola principis H. de Boiss.: an application of SRXRF microprobe. Chemosphere 72: 1491-1496.

Liu W, Shu WS, Lan CY (2004). Viola baoshanensis, a plant that hyperaccumulates cadmium. Chinese Science Bulletin 49: 29-32.

Marcussen T, Heier L, Brysting AK, Oxelman B, Jakobsen KS (2015) From gene trees to a dated allopolyploid network: insights from the angiosperm genus Viola (Violaceae). Systematic Biology 64: 84-101.

Özdeniz E, Özbey BG, Kurt L, Bölükbaşı A (2017). Serpantin ekolojisi ve Türkiye serpantin florasına katkılar. Toprak Bilimi ve Bitki Besleme Dergisi 5(1): 22-33.

Peng JS, Guan, YH, Lin, XJ, Xu XJ, Xiao L, Wang HH, Meng S (2020). Comparative understanding of metal hyperaccumulation in plants: a mini-review. Environmental Geochemistry and Health 42(2): 1-9.

Prasad MNV (2005). Nickelophilous plants and their significance in phytotechnologies. Brazilian Journal of Plant Physiology 17: 113-128.

Reeves RD (1988). Nickel and zinc accumulation by species of Thlaspi L., Cochlearia L. and other genera of the Brassicaceae. Taxon 37: 309-318.

Reeves RD, Adigüzel N (2004). Rare plants and nickel accumulators from Turkish serpentine soils, with special reference to Centaurea species. Turkish Journal of Botany 28: 147-153.

Reeves RD, Adıgüzel N (2008). The nickel hyperaccumulating plants of the serpentines of Turkey and adjacent areas: a review with new data. Turkish Journal of Botany 32: 143-153.

Reeves RD, Adigüzel N, Baker AJM (2009). Nickel hyperaccumulation in Bornmuellera kiyakii Aytaç \& Aksoy and associated plants of the Brassicaceae from Kızıldağ Derebucak (Konya), Turkey. Turkish Journal of Botany 33: 33-40. 
Reeves RD, Baker AJ, Jaffré T, Erskine PD, Echevarria G, \& van der Ent A (2018). A global database for plants that hyperaccumulate metal and metalloid trace elements. New Phytologist 218(2): 407-411.

Reeves RD, Brooks RR, Dudley TR. 1983. Uptake of nickel by species of Alyssum, Bornmuellera and other genera of Old World Tribus Alysseae. Taxon 32: 184-192.

Reeves RD, Kruckeberg AR, Adıgüzel N, Kramer U (2001). Studies on the flora of serpentine and other metalliferous areas of western Turkey. South African Journal of Science 97: 513-517.

Remigio AC, Chaney RL, Baker AJM, Edraki M, Erskine PD, Echevarria G, van der Ent A, (2020). Phytoextraction of high value elements and contaminants from mining and mineral wastes: Opportunities and limitations. Plant and Soil 449: 11-37.

Stevanović B, Drazic G, Tomović G, Sinzar-Sekulic J, Melovski L, Novovic I, Markovic DM (2010). Accumulation of arsenic and heavy metals in some Viola species from an abandoned mine, Alchar, Republic of Macedonia (Fyrom). Plant Biosystems 144(3): 644-655.

Sychta K, Słomka A, Suski S, Fiedor E, Gregoraszczuk E, Kuta E (2018). Suspended cells of metallicolous and nonmetallicolous Viola species tolerate, accumulate and detoxify zinc and lead. Plant Physiology and Biochemistry 132: 666-674.

Tomović G, Đurović S Buzurović U, Niketić M, Milanović D, Mihailović N, and Jakovljević K (2021). Accumulation of potentially toxic elements in Viola L. (sect. Melanium Ging.) from the ultramafic and non-ultramafic soils of the Balkan peninsula. Water Air and Soil Pollution 23(46): 1-18.

Tonin C, Vandenkoornhuyse P, Joner EJ, Straczek J, Leyval C (2001). Assessment of arbuscular mycorrhizal fungi diversity in the rhizosphere of Viola calaminaria and effect of these fungi on heavy metal uptake by clover. Mycorrhiza, 10: 161-168.

Van der Ent A, Baker AJM, Reeves RD, Pollard AJ, Schat H (2013). Hyperaccumulars of metal and metalloid trace elements: facts and fiction. Plant Soil 262: 319-324.

Wei L, Wensheng S, Chongyu L (2004). Viola boashanensis, a plant that hyperaccumulates cadmium. Chinese Science Bulletin 49(1): 29-32.

Wu C, Liao B, Wang SL, Zhang J, Li JT (2010). Pb and Zn Accumulation in a Cd-Hyperaccumulator (Viola boashanensis). International Journal of Phytoremediation 12: 574-585.

Yıldırımlı Ş (2000). Viola L. in: A Güner, N Özhatay, T Ekim and KHC Başer (eds.), Flora of Turkey and the East Aegean Islands, v. 11. Edinburgh: Edinburgh Univ. Press, pp. 43-44. 